\title{
Synovial Cysts in the Temporomandibular Joint: a Case Report and Critical Review of the Literature
}

\author{
Ynn Maribo ${ }^{1}$, Kasper Stokbro ${ }^{1,2}$, Esben Aagaard ${ }^{1}$, Stine Rosenkilde Larsen $^{3}$, Torben Thygesen ${ }^{1}$ \\ ${ }^{1}$ Department of Oral and Maxillofacial Surgery, Odense University Hospital, Denmark. \\ ${ }^{2}$ Clinical institute, Faculty of Health, University of Southern Denmark, Denmark. \\ ${ }^{3}$ Department of Pathology, Odense University Hospital, Denmark.
}

\author{
Corresponding Author: \\ Kasper Stokbro \\ Department of Oral and Maxillofacial Surgery \\ Odense University Hospital \\ Sdr. Boulevard 29, 5000 Odense C \\ Denmark \\ Phone: $(+45) 65413475$ \\ Fax: $(+45) 66148226$ \\ E-mail: kasper.stokbro@,rsyd.dk
}

\begin{abstract}
Background: Synovial cysts of the temporomandibular joint are rare and treatment is based on consensus from cases reporting unilateral successful outcomes. A patient with a synovial cyst is presented, treated with successful surgical excision of the cyst, but without remission of joint symptoms. Furthermore, the case is supplemented by a critical, literature review.

Methods: This case report deals with a patient with a synovial cyst that presented with temporomandibular joint (TMJ) pain and reduced mouth opening. Magnetic resonance imaging verified a TMJ cyst.

Results: Surgical excision removed the synovial cyst, and the patient was followed-up for 4 years, with no recurrence of the cyst. Despite successful excision of the cyst, the symptoms did not subside, and the patient is still in treatment. The critical, literature review found 23 case reports describing 24 synovial cysts. In addition, 4 cases were included as their synovial cysts were erroneously described as ganglion cysts. In 4 cases, histological diagnosis could not be confirmed, and they were excluded. All cases described treatment by surgical excision without recurrence. The reported median follow-up was 10 months and postoperative TMJ symptoms were rarely examined or described.

Conclusions: The temporomandibular joint symptoms may persist despite successful removal of the synovial cyst. Furthermore, the 4 identified synovial cysts, mislabelled as ganglion cysts, represents almost a quarter of the cases of the reported synovial cysts. Correct labelling and reporting of synovial cysts are still imperative to describe the diverse aspects of treatment outcomes following surgical excision.
\end{abstract}

Keywords: ganglion cysts; magnetic resonance imaging; synovial cyst; temporomandibular joint disorder.

\section{Accepted for publication: 19 January 2019}

To cite this article:

Maribo Y, Stokbro K, Aagaard E, Larsen SR, Thygesen T.

Synovial Cysts in the Temporomandibular Joint: a Case Report and Critical Review of the Literature

J Oral Maxillofac Res 2019;10(1):e4

URL: http://www.ejomr.org/JOMR/archives/2019/1/e4/v10n1e4.pdf

doi: $10.5037 /$ jomr.2019.10104 


\section{INTRODUCTION}

Synovial cysts are true synovial-lined cysts arising from displaced or herniated synovial lining, which may communicate with the joint cavity. Synovial cysts are associated with primary traumatic or inflammatory processes and may be caused by increased intraarticular pressure [1-3]

Ganglion cysts are pseudocysts formed by a fibrous connective tissue wall and myxoide degenerative changes without synovial cell lining or connection with the joint cavity [2]. The degeneration of connective tissue is caused by irritation or chronic damage to mesenchymal cells or fibroblasts, inducing production of excessive mucin [3] .

Ganglion and synovial cysts are expansile, fluid-filled lesions of the joint, located mainly in periarticular areas of the wrist, knee or ankle [2], and rarely in the temporomandibular joint (TMJ). A clear distinction between these two entities is rarely made in publications [2].

Synovial cysts are indistinguishable from ganglion cysts, both clinically and radiographically [4], so exact diagnosis must be confirmed by histological analysis, confirming the presence of a synovial lining [2]. The condition is often associated with pain and sparse clinical findings.

We present a case of a histologically confirmed TMJ synovial cyst with 4 years' follow-up. Furthermore, we present a critical review of the literature regarding the diagnosis, treatment and recurrence of synovial cysts.

\section{CASE DESCRIPTION AND RESULTS}

On the $2^{\text {nd }}$ of May, 2011, a 52-year-old female was referred to the Department of Oral and Maxillofacial
Surgery, Odense University Hospital, Odense, Denmark, after conservative treatment failed to relieve the patient's temporomandibular pain. The patient had no history of traumatic injury but presented with severe TMJ pain.

The patient experienced pain from the left TMJ (visual analogue scale [VAS] score of 5 - 9) that extended to the left eye accompanied by daily migraine symptoms. The pain was treated with tramadol and paracetamol daily. The masticatory muscles were strained and tender upon palpation. The patient had a maximal mouth opening of $45 \mathrm{~mm}$ with pain during the entire movement and crepitus from the left joint and clicking from the right joint. Oral examination revealed no pathologic changes and normal occlusion.

Computed tomography showed irregular bony surfaces with subchondral cysts in the mandibular condyles, most prominent in the left condyle. Magnetic resonance imaging (MRI) showed a cystlike structure, $9 \mathrm{~mm}$ in diameter, in front of the left auditory meatus and distal to the collum mandibulae (Figure 1). No degenerative changes were described.

Bilateral arthroscopy and arthrocentesis showed a disc perforation in the left TMJ and anterior disc displacement with a thickened disc, thus corresponding to chondromalacia stage II of the right joint. Modest synovial changes were observed bilaterally. Hyaluronic acid and Bupivacaine were injected bilaterally. The patient was discharged with TMJ exercises (stretching + mouth opening). At 2-month follow-up after surgical procedures there was no change in pain perception, and a MRI showed no changes in the diameter of the cyst.

Based on the clinical findings, the cyst was excised via a preauricular approach. The upper joint chamber was explored to undermine the adhesion to the lateral wall of the joint capsule and excise the cyst in toto. The cyst was perforated during blunt dissection

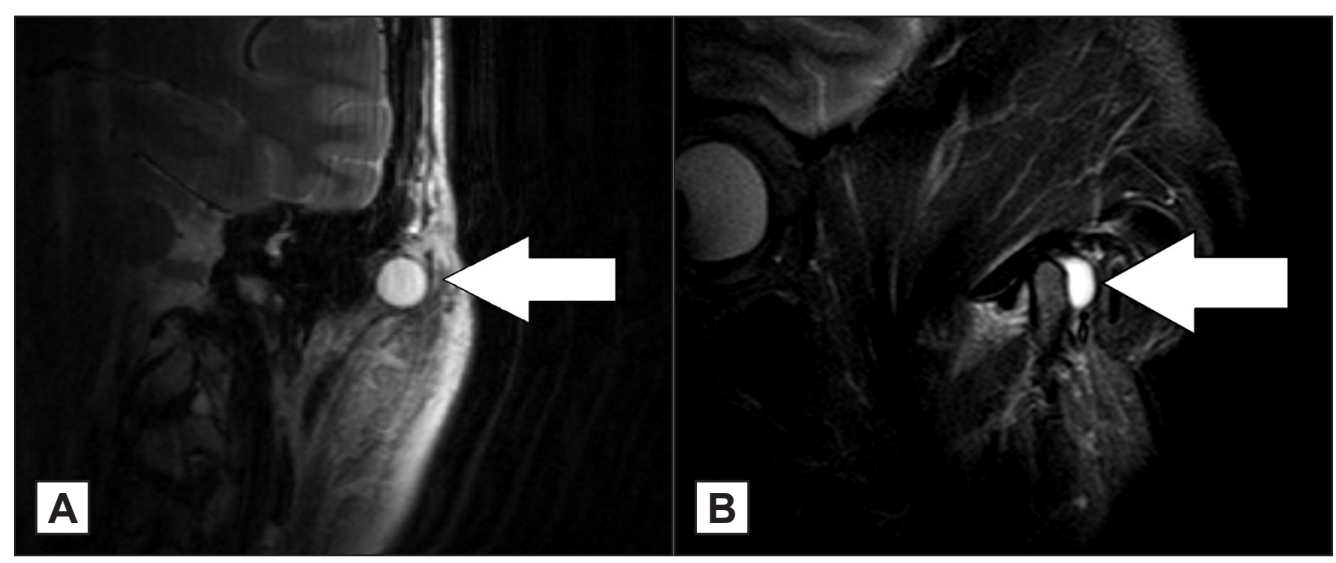

Figure 1. Preoperative T2-weighted magnetic resonance image. Magnetic resonance imaging of the synovial cyst in the left temporomandibular joint. $\mathrm{A}=$ the synovial cyst is visualized in the coronal plane. $\mathrm{B}=$ the synovial cyst is visualized in the axial plane. The cyst is marked by a white arrow. The cyst lumen is fluid filled, making the cyst lumen bright on the T2-weighted MRI. 
and leaked clear, gelatinous material. The cyst was removed and sent for histopathological examination (Figures 2 - 3). Haematoxylin eosin stained sections showed a cystic-like structure walled by synovial cells. Myxoide degeneration was observed in the cyst wall. These finding were consistent with the histological and clinical diagnosis of a synovial cyst (Figure 4).

At 3-month follow-up, the patient had dysesthesia in the left auricular and preauricular areas, extending to the temporal bone, described as a prickling sensation. Clinical examination showed normal facial nerve function and maximal mouth opening of $34 \mathrm{~mm}$ with reduced translation in the left TMJ.

At 6-month follow-up, MRI confirmed cyst removal without recurrence. Significant postoperative degenerative changes were described in the form of irregular condylar bone contours, oedema of muscle and oedema in the TMJ. The patient reported a reduction of the neuralgiform pain (VAS score 5). Conservative management of TMJ symptoms was initiated with mouth opening exercises, infrared heat application and NSAID analgesic treatment was performed.

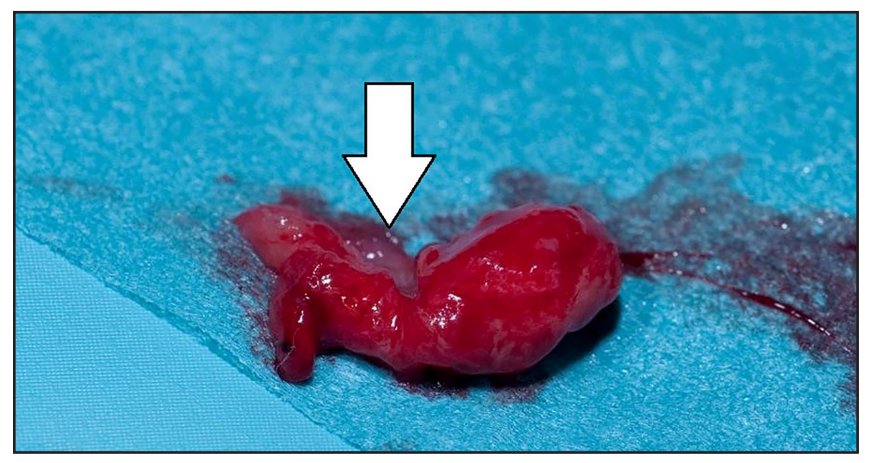

Figure 2. Perioperative photo of synovial cyst excision. White arrow marks synovial cyst.

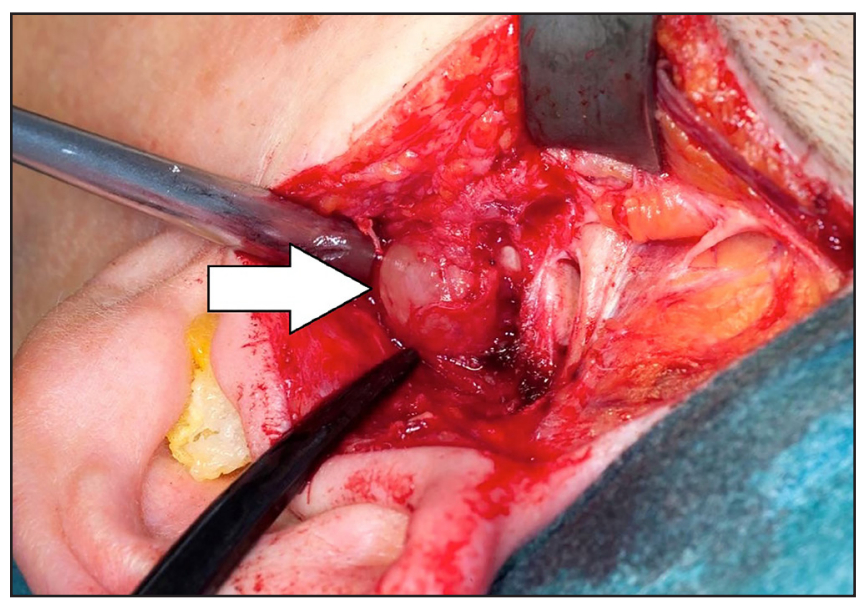

Figure 3. Synovial cyst following excision.

Note clear gelatinous material leaking from the cyst, marked by the white arrow.
At 18-month follow-up, the patient complained of intermitting shooting pain in the left side of the face and a feeling of changed occlusion. Clinically, the patient had maximal mouth opening of $45 \mathrm{~mm}$ with a minimal deviation to the left.

At 2.5-year follow-up, the patient was still in pain, the VAS score was unchanged, and she complained of discomfort related to the TMJ in general. Normal occlusion was observed

At 4-year follow-up, the pain/VAS score was unchanged. The patient still complained of functional pain and clicking from the TMJ. The masticatory muscles were tender upon palpation. Maximal mouth opening was unchanged. All the presented symptoms were similar to the initial preoperative symptoms. A new MRI showed no recurrence of the synovial cyst.

\section{Critical, literature review}

A systematic search of the literature was performed to critically appraise the existing knowledge regarding synovial cysts. Pubmed was searched using a combination of the following search words: [Synovial] AND [Cyst] AND [Temporomandibular Joint]. The search was limited to articles published in the English language from May 1977 to January 2019.

Inclusion criteria: clinical treatment of ganglion or synovial cyst in relation to the TMJ, either in trials or as case reports.

Exclusion criteria: foreign language (other than English), identical case reports, histological description or image not available to confirm synovial cyst or does not support the diagnosis.

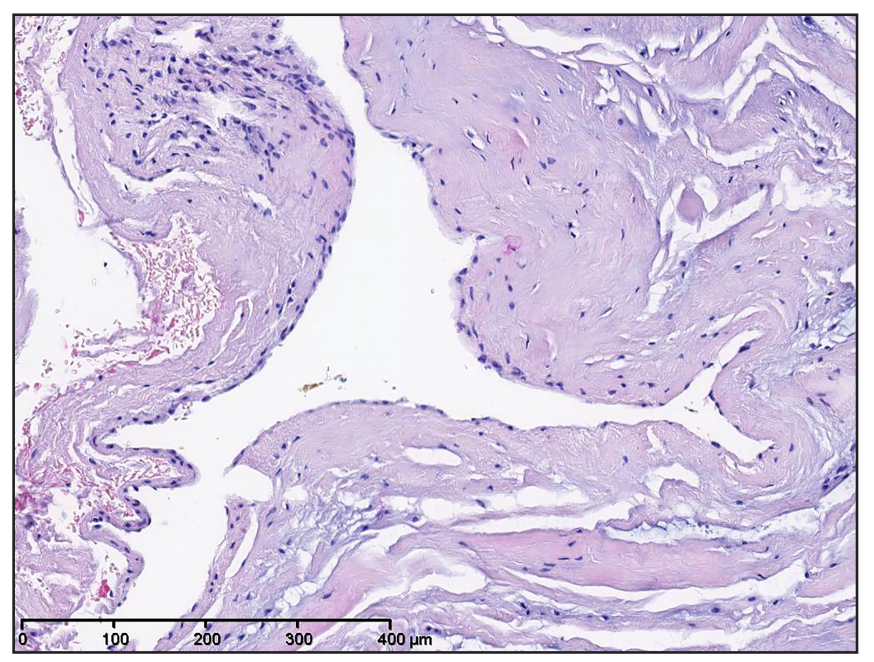

Figure 4. Histology shows a folded cystic structure lined by flattened synovial cells (original magnification x100).

In the cyst wall myxoid degeneration is observed (hematoxylin and eosin staining). 
The quality of all included case reports was evaluated by a modification of the Newcastle-Ottawa scale for cohort studies []․ The scale was modified by evaluating only for selection ("Ascertainment of exposure") and outcome ("Assessment of outcome" and "Follow-up length") as was deemed pertinent for the considered case reports. Adequate followup length was defined as 1 year for recurrence of synovial cyst and TMJ symptoms. One star could be given for each accomplished item with a maximum of 3 stars.

The initial search resulted in 40 articles $[1-4, \underline{6-}$ 41] describing 59 patients with 61 cysts, mean age 43 years (range 11 to 88 ), in 40 female and 19 male patients (Table 1). The full-length articles were screened in detail according to the exclusion criteria. After thorough reading of all the histological descriptions, it was concluded that 4 cases reported as ganglion cysts were erroneously diagnosed and were in fact true synovial cysts according to the authors' published histology $[\underline{13}, \underline{19}, \underline{28}, \underline{29}]$ (text and/or histological image). Furthermore, histological findings in 4 cysts in 3 articles were found to be insufficiently described, and these 4 cysts were therefore not included in the study $[\underline{4}, \underline{12}, \underline{30}]$. Attempts were made to contact the authors with the aim of specification of histology but without success. One study was included despite lack of histological material, since the authors performed blinded re-evaluation of the samples using immunohistochemical analysis [41]. The description or histopathology was consistent with synovial cyst in 23 patients, a total of 24 cysts. Findings regarding the 24 synovial cysts are summarized in Table 2.

The quality of all included case reports was assessed according to the modified Newcastle-Ottawa scale [ㅁ] . All included articles received a star, for ascertainment of synovial cysts following critical evaluation of the histological image or description, but only 6 reports received additional stars in outcome reporting (Table $3)$. Thus, the majority of case reports received a poor-quality assessment with 9 reports obtaining only 1 star, 2 case reports received a medium-quality assessment score with 2 stars, and 4 case reports received a high-quality assessment with 3 stars.

Synovial cysts occurred in females in 53\% (8 of 15) of the cases, and the median age at presentation was 48 years (range 22 to 88 ). The main symptoms of a synovial cyst were swelling $64 \%$ (9 of 14 ), pain $57 \%$ ( 8 of 14) and reduced mouth opening 50\% (5 of 10). Prior trauma to the affected joint was described in $33 \%$ (3 of 9). A computed tomography was performed in 10 cases, MRI in 10 cases, ultrasound in 2 cases and a conventional X-ray in 1 case. Surgical removal was performed in all the cases $(100 \%)$. Follow-up was described in 9 of the cases, median 10 months ( 2 weeks - 18 months), with no recurrence in the 5 cases where radiographic follow-up was performed. Postoperative TMJ pain and function was mentioned in 4 cases. None of the 4 cases reported postoperative pain, which was an improvement for 3 patients. TMJ function improved to normal for 3 cases, but in 1 case mouth opening was unaffected by surgery and remained at $35 \mathrm{~mm}$. The remaining cases did not specify TMJ function following surgical removal of the cyst.

\section{DISCUSSION}

We report a case of a 52-year-old woman initially presenting with TMJ pain. She had no prior trauma, normal mouth opening and experienced no preauricular swelling. MRI identified a cystlike structure in relation to the TMJ. The structure was removed by surgical excision, and histological examination confirmed the diagnosis of a true synovial cyst. The patient was followed-up for 4 years, and there was no recurrence. However, the TMJ pain did not subside despite successful excision of the synovial cyst, and she is still undergoing treatment for the TMJ disorder and pain.

When discussing the patient's postoperative recovery and pain, one must not overlook neuralgiform pain. At 3-month postoperative follow-up, the patient noticed altered sensation in the area, described as pinprick sensations. It's not unrealistic to suggest that there had been a perioperative injury to the auriculotemporal nerve with subsequent development of dysesthesia in the area.

The critical literature review identified 23 patients (24 cysts) of histologically verifiable synovial cysts. We also included in our review 4 cases reported as ganglion cysts in the literature because histological analysis showed true synovial cysts $[\underline{13}, \underline{19}, \underline{28}, \underline{29}]$.

The terms ganglion cyst and synovial cyst are used interchangeably in spite of their different natures. Various clinical findings as well as subjective symptoms occur in the presence of both types of cyst. Clinical presentations alone cannot be used to make the diagnosis. Radiographic presentation is an important tool to identify cysts and rule out other diagnoses, but accurate diagnosis is only possible by histological analysis or intraoperatively by finding in case of a connection between the cyst and the TMJ. The differential diagnosis of TMJ tumour includes parotid mass, ganglion cyst, synovial cyst, retention cyst, sebaceous cyst, benign cervical lumphoepithelial cyst, and benign vascular and neural tumours. 
Table 1. Initial screening in critical review of the literature

\begin{tabular}{|c|c|c|c|c|}
\hline Author & Age & Gender & Diagnosis according to text & Histological diagnosis \\
\hline Ansari et al. [1] & 63 & $\mathrm{~F}$ & Synovial cyst & Synovial cyst \\
\hline Vera-Siera et al. [2] & 48 & $\mathrm{~F}$ & Synovial cyst & Synovial cyst \\
\hline Suhr and Mager [3] & 30 & M & Ganglion cyst & Ganglion cyst \\
\hline \multirow{2}{*}{ Okochi et al. [4] } & \multirow{2}{*}{$20-59$} & $3 \mathrm{~F}$ & 2 synovial cysts & \multirow{2}{*}{$\mathrm{NA}^{\mathrm{a}}$} \\
\hline & & $3 \mathrm{M}$ & 4 ganglion cysts & \\
\hline Wu et al. [6] & 59 & $\mathrm{~F}$ & Ganglion cyst & Ganglion cyst \\
\hline Spinzia et al. [7] & 45 & $\mathrm{~F}$ & Synovial cyst & Synovial cyst \\
\hline Hinawi et al. [8] & 11 & M & Ganglion cyst & Ganglion cyst \\
\hline Ali et al. [9] & 28 & $\mathrm{~F}$ & Ganglion cyst & Ganglion cyst \\
\hline Kim et al. [10] & 37 & $\mathrm{~F}$ & Ganglion cyst & Ganglion cyst \\
\hline Takaku et al. [11] & 50 & $\mathrm{~F}$ & Ganglion cyst & Ganglion cyst \\
\hline Lomeo et al. [12] & 47 & $\mathrm{~F}$ & Synovial cyst & $\mathrm{NA}^{\mathrm{a}}$ \\
\hline Albright et al. [13] & 51 & $\mathrm{~F}$ & Ganglion cyst & Synovial cyst \\
\hline Nahlieli et al. [14] & 57 & $\mathrm{~F}$ & Ganglion cyst & Ganglion cyst \\
\hline \multirow{2}{*}{ Goudot et al. [15] } & 35 & M & Ganglion cyst & Ganglion cyst \\
\hline & 65 & M & Synovial cyst & Synovial cyst \\
\hline \multirow{2}{*}{ Chang et al. [16] } & 32 & $\mathrm{~F}$ & Ganglion cyst & Ganglion cyst \\
\hline & 38 & M & Synovial cyst & Synovial cyst \\
\hline Bonacci et al. [17] & 46 & M & Synovial cyst & Synovial cyst \\
\hline Lopes et al. [18] & 33 & $\mathrm{~F}$ & Ganglion cyst & Ganglion cyst \\
\hline McGuirt el al. [19] & 54 & $\mathrm{~F}$ & Ganglion cyst & Synovial cyst \\
\hline Hopper and Banks [20] & 58 & $\mathrm{~F}$ & Ganglion cyst & Ganglion cyst \\
\hline Farole and Johnson [21] & 22 & M & 2 synovial cysts & 2 synovial cysts \\
\hline Tom et al. [22] & 22 & $\mathrm{M}$ & 2 ganglion cysts & NA \\
\hline El-Massry and Bailey [23] & 33 & $\mathrm{~F}$ & Ganglion cyst & Ganglion cyst \\
\hline Copeland and Douglas [24] & 60 & $\mathrm{~F}$ & Ganglion cyst & NA \\
\hline Shiba et al. [25] & 28 & M & Ganglion cyst & Ganglion cyst \\
\hline Kenney et al. [26] & 64 & $\mathrm{~F}$ & Ganglion cyst & NA \\
\hline Reychler et al. [27] & 30 & $\mathrm{~F}$ & Synovial cyst & Synovial cyst \\
\hline Kinkead et al. [28] & 36 & $\mathrm{~F}$ & Ganglion cyst & Synovial cyst \\
\hline Ethell [29] & 28 & $\mathrm{~F}$ & Ganglion cyst & Synovial cyst \\
\hline Janecka and Conley [30] & 50 & $\mathrm{M}$ & Synovial cyst & $\mathrm{NA}^{\mathrm{a}}$ \\
\hline Deng et al. [31] & 45 & $\mathrm{~F}$ & Ganglion cyst & Ganglion cyst \\
\hline Silva et al. [32] & 51 & $\mathrm{~F}$ & Ganglion cyst & Ganglion cyst \\
\hline Neis et al. [33] & 57 & M & Synovial cyst & Synovial cyst \\
\hline Chen et al. [34] & 59 & M & Synovial cyst & Synovial cyst \\
\hline Patel et al. [35] & 45 & $\mathrm{~F}$ & Ganglion cyst & Ganglion cyst \\
\hline Heydt [36] & 47 & F & Ganglion cyst & Ganglion cyst \\
\hline Steen and Hofstede [37] & 48 & $\mathrm{~F}$ & Ganglion cyst & Ganglion cyst \\
\hline Zheng et al. [38] & 24 & M & Ganglion cyst & Ganglion cyst \\
\hline Lee et al. [39] & 48 & $\mathrm{M}$ & Ganglion cyst & Ganglion cyst \\
\hline Levarek and Nolan [40] & 88 & $\mathrm{~F}$ & Ganglion cyst & Ganglion cyst \\
\hline \multirow{2}{*}{ Partridge et al. [41] } & \multirow{2}{*}{$17-84$} & $11 \mathrm{~F}$ & 9 synovial cysts & 9 synovial cysts \\
\hline & & $2 \mathrm{M}$ & 4 ganglion cysts & 4 ganglion cysts \\
\hline Total & Mean $43(11-88)$ & $40 \mathrm{~F} / 19 \mathrm{M}$ & 24/61 synovial cyst & 24/49 synovial cyst \\
\hline
\end{tabular}

${ }^{a}$ Attempts were made to contact the authors with the aim of specification of histology but without success.

$\mathrm{F}=$ female $; \mathrm{M}=$ male $; \mathrm{NA}=$ not available. 
Table 2. Articles included after critical review of the literature

\begin{tabular}{|c|c|c|c|c|c|c|c|c|c|c|c|c|}
\hline & Age & Gender & $\begin{array}{l}\text { TMJ } \\
\text { pain }\end{array}$ & $\begin{array}{l}\text { Mouth } \\
\text { opening }\end{array}$ & Swelling & Trauma & Imaging & Treatment & Follow-up & Recurrence & $\begin{array}{c}\text { TMJ pain } \\
\text { postoperative }\end{array}$ & $\begin{array}{c}\text { Mouth } \\
\text { opening } \\
\text { postoperative }\end{array}$ \\
\hline Ansari et al. [1] & 63 & $\mathrm{~F}$ & No & NA & No & No & MR & $\begin{array}{l}\text { Surgical } \\
\text { removal }\end{array}$ & NA & NA & NA & NA \\
\hline Vera-Siera et al. [2] & 48 & $\mathrm{~F}$ & Yes & Normal & Yes & No & $\mathrm{CT}+\mathrm{MR}$ & $\begin{array}{l}\text { Surgical } \\
\text { removal }\end{array}$ & 6 months & NA & No & Normal \\
\hline Spinzia et al. [7] & 45 & $\mathrm{~F}$ & No & Normal & Yes & No & $\mathrm{US}+\mathrm{CT}$ & $\begin{array}{l}\text { Surgical } \\
\text { removal }\end{array}$ & 18 months & No & NA & NA \\
\hline Albright et al. [13] & 51 & $\mathrm{~F}$ & No & $35 \mathrm{~mm}$ & No & No & $\mathrm{CT}+\mathrm{MR}$ & $\begin{array}{l}\text { Surgical } \\
\text { removal }\end{array}$ & 8 months & No & No & $35 \mathrm{~mm}$ \\
\hline Goudot et al. [15] & 65 & M & No & Reduced & No & Yes & $\mathrm{CT}+\mathrm{MR}$ & $\begin{array}{l}\text { Surgical } \\
\text { removal }\end{array}$ & NA & NA & NA & NA \\
\hline Chang et al. [16] & 38 & M & Yes & NA & Yes & Yes & X-ray + MR & $\begin{array}{l}\text { Surgical } \\
\text { removal }\end{array}$ & 18 months & No & NA & NA \\
\hline Bonacci et al. [17] & 46 & M & Yes & Reduced & Yes & No & $\mathrm{US}+\mathrm{MR}$ & $\begin{array}{l}\text { Surgical } \\
\text { removal }\end{array}$ & 1 year & No & No & $50 \mathrm{~mm}$ \\
\hline Mcguirt el al. [19] & 54 & $\mathrm{~F}$ & Yes & Reduced & Yes & No & $\mathrm{CT}+\mathrm{MR}$ & $\begin{array}{l}\text { Surgical } \\
\text { removal }\end{array}$ & NA & NA & NA & NA \\
\hline Farole and Johnson [21] & 22 & M & Yes & Normal & No & NA & $\mathrm{CT}+\mathrm{MR}$ & $\begin{array}{l}\text { Surgical } \\
\text { removal }\end{array}$ & 1 year & No & No & Normal \\
\hline Reychler et al. [27] & 30 & $\mathrm{~F}$ & Yes & $28 \mathrm{~mm}$ & Yes & Yes & $\mathrm{CT}$ & $\begin{array}{l}\text { Surgical } \\
\text { removal }\end{array}$ & 2 weeks & NA & NA & NA \\
\hline Kinkead et al. [28] & 36 & $\mathrm{~F}$ & Yes & Normal & Yes & NA & NA & $\begin{array}{l}\text { Surgical } \\
\text { removal }\end{array}$ & NA & NA & NA & NA \\
\hline Ethell [29] & 28 & $\mathrm{~F}$ & No & NA & Yes & NA & NA & $\begin{array}{l}\text { Surgical } \\
\text { removal }\end{array}$ & 4 months & NA & NA & NA \\
\hline Neis et al. [33] & 57 & M & No & NA & NA & NA & $\mathrm{CT}+\mathrm{MR}$ & $\begin{array}{l}\text { Surgical } \\
\text { removal }\end{array}$ & 1 year & NA & NA & NA \\
\hline Chen et el. [34] & 59 & M & NA & NA & Yes & NA & $\mathrm{CT}$ & $\begin{array}{l}\text { Surgical } \\
\text { removal }\end{array}$ & NA & NA & NA & NA \\
\hline Partridge et al. [41] & $\begin{array}{c}9 \mathrm{pt} \\
17-84\end{array}$ & NA & NA & NA & NA & NA & NA & $\begin{array}{l}\text { Surgical } \\
\text { removal }\end{array}$ & NA & NA & NA & NA \\
\hline
\end{tabular}

$\mathrm{TMJ}=$ temporomandibular join; $\mathrm{F}=$ female; $\mathrm{M}=$ male; $\mathrm{NA}=$ not available; $\mathrm{MR}=$ magnetic resonance $\mathrm{CT}=$ computed tomography. $\mathrm{US}=\mathrm{ultrasound}$ sonogram; $\mathrm{pt}=$ patients. 
Table 3. Modified Newcastle-Ottawa scale for assessment of quality of included case reports

\begin{tabular}{|c|c|c|c|c|}
\hline & $\begin{array}{l}\text { Ascertainment of } \\
\text { synovial cyst? }\end{array}$ & $\begin{array}{l}\text { Objective } \\
\text { assessment of } \\
\text { outcome? }\end{array}$ & $\begin{array}{c}\text { Follow-up } \\
\text { long enough } \\
\text { for recurrence to occur?a }\end{array}$ & Total \\
\hline Ansari et al. [1] & $\Leftrightarrow$ & & & 1 \\
\hline Vera-Siera et al. [2] & 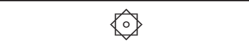 & & & 1 \\
\hline Spinzia et al. [7] & $\Leftrightarrow$ & $\Leftrightarrow$ & $\Leftrightarrow$ & 3 \\
\hline Albright et al. [13] & $\Leftrightarrow$ & $\Leftrightarrow$ & & 2 \\
\hline Goudot et al. [15] & $\&$ & & & 1 \\
\hline Chang et al. [16] & 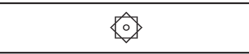 & $\Leftrightarrow$ & $\&$ & 3 \\
\hline Bonacci et al. [17] & 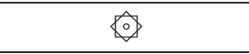 & $\Leftrightarrow$ & $\Leftrightarrow$ & 3 \\
\hline Mcguirt el al. [19] & $\Leftrightarrow$ & & & 1 \\
\hline Farole and Johnson [21] & $\Leftrightarrow$ & $\Leftrightarrow$ & $\Leftrightarrow$ & 3 \\
\hline Reychler et al. [27] & $\&$ & & & 1 \\
\hline Kinkead et al. [28] & $\Leftrightarrow$ & & & 1 \\
\hline Ethell [29] & 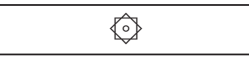 & & & 1 \\
\hline Neis et al. [33] & $\&$ & & $\Leftrightarrow$ & 2 \\
\hline Chen et el. [34] & $\Leftrightarrow$ & & & 1 \\
\hline Partridge et al. [41] & $\Longleftrightarrow$ & & & 1 \\
\hline
\end{tabular}

aDefined as 12-months follow-up.

Other lesions include primary and metastatic tumours of the condyle, chondromatosis and crystal arthropathies [ $[\underline{6}, 7]$.

The pain and discomfort from the TMJ did not disappear despite successful excision of the synovial cyst and no evidence of recurrence. TMJ disorders are multifactorial, and the cause of the pain and discomfort may have been caused by the disc perforation and displacement rather than the synovial cyst. Thus, it is important to address all TMJ problems during the open joint surgery to minimize the need for additional surgical procedures. Furthermore, the continued inflammation of the joint may cause recurrence of the cyst. Therefore, it is still important to monitor and treat the patient until the TMJ symptoms subside.

With this in mind, it is noteworthy that followup was mentioned in $39 \%$ of the cases reported in the literature, and in only $9 \%$ for more than 1 year. Fortunately, the recurrence rate of TMJ synovial cysts seems to be low, and recurrence has not been reported in the literature $[\underline{7}, \underline{13}, 16,21]$. Therefore, it has also been suggested that synovial cyst may be developmental in origin. However, until more knowledge is acquired, we advise monitoring and treating patients until TMJ disorder's symptoms recede.
Treatment of synovial cysts is based on consensus, due to the rarity of occurrence. It is therefore important to document the broad range of clinical findings and thus encourage continued reporting of these cases.

\section{CONCLUSIONS}

A synovial cyst of the temporomandibular joint is rare, with only 23 histologically verified case reports in the literature. Magnetic resonance imaging remains the gold standard for the initial diagnosis of temporomandibular joint cysts and the exclusion of other diagnoses. Surgical excision remains the "gold standard" of care and all joint and disc problems should be addressed during the open joint surgery. Patients should be monitored until persisting symptoms of the involved joint subside.

\section{ACKNOWLEDGMENTS AND DISCLOSURE STATEMENTS}

The authors report no conflicts of interest related to this study. 


\section{REFERENCES}

1. Ansari H, Robertson CE, Lane JI, Viozzi CF, Garza I. Auriculotemporal neuralgia secondary to TMJ synovial cyst: a rare presentation of a rare entity. Headache. 2013 Nov-Dec;53(10):1662-5. [Medline: 24020967] [doi: 10.1111/head.12196]

2. Vera-Sirera B, Tomás-Amerigo JA, Baquero C, Vera-Sempere FJ. Synovial cysts of the temporomandibular joint: an immunohistochemical characterization and literature review. Case Rep Pathol. 2013;2013:508619. [Medline: 23573446] [PMC free article: $\underline{3616358]}$ [doi: 10.1155/2013/508619]

3. Suhr MA, Mager A. Unilateral non-occlusion secondary to a ganglionic cyst of the temporomandibular joint (TMJ). J Craniomaxillofac Surg. 2013 Jan;41(1):e5-7. [Medline: 22575328] [doi: 10.1016/j.jcms.2012.03.017]

4. Okochi K, Nakamura S, Tetsumura A, Honda E, Kurabayashi T. Magnetic resonance imaging of temporomandibular joint cyst. Oral Surg Oral Med Oral Pathol Oral Radiol. 2012 Jun;113(6):827-31. [Medline: 22668711] [doi: 10.1016/j.oooo.2011.11.013]

5. Wells GA, Shea B, O’Connell D, Peterson J, Welch V, Losos M, Tugwell P. The Newcastle-Ottawa Scale (NOS) for assessing the quality of nonrandomised studies in meta-analyses. [URL: www.ohri.ca/programs/clinical epidemiology/ oxford.asp]

6. Wu CI, Liu KW, Hsu YC, Chiang IP, Chang SC. Treatment of temporomandibular joint ganglion cyst. J Craniofac Surg. 2011 Sep;22(5):1935-7. [Medline: 21959472] [doi: 10.1097/SCS.0b013e318211516d]

7. Spinzia A, Panetta D, Russo D, Califano L. Synovial cyst of the temporomandibular joint: a case report and literature review. Int J Oral Maxillofac Surg. 2011 Aug;40(8):874-7. [Medline: 21470821] [doi: 10.1016/j.ijom.2011.02.027]

8. Shinawi M, Hicks J, Guillerman RP, Jones J, Brandt M, Perez M, Lee B. Multiple ganglion cysts ('cystic ganglionosis'): an unusual presentation in a child. Scand J Rheumatol. 2007 Mar-Apr;36(2):145-8. [Medline: 17476622] [doi: $10.1080 / 03009740601089275]$

9. Ali ZA, Busaidy KF, Wilson J. Unusual presentation of a ganglion cyst of the temporomandibular joint: case report and distinction from synovial cyst. J Oral Maxillofac Surg. 2006 Aug;64(8):1300-2. [Medline: 16860230] [doi: 10.1016/j.joms.2006.04.013]

10. Kim SG, Cho BO, Lee YC, Hong SP, Chae CH. Ganglion cyst of the temporomandibular joint. J Oral Pathol Med. 2003 May;32(5):310-3.. [Medline: 12694356] [doi: 10.1034/j.1600-0714.2003.00115.x]

11. Takaku S, Sano T, Komine Y, Fukazawa N. Ganglion of the temporomandibular joint: case report. J Oral Maxillofac Surg. 2001 Feb;59(2):224-8. [Medline: 11213996] [doi: 10.1053/joms.2001.20506]

12. Lomeo PE, McDonald JE, Finneman J. Temporomandibular joint cyst as a preauricular mass. Am J Otolaryngol. 2000 Sep-Oct;21(5):331-2. [Medline: 11032299] [doi: 10.1053/ajot.2000.16168]

13. Albright JT, Diecidue RJ, Johar A, Keane WM. Intraosseous ganglion of the temporomandibular joint presenting with otorrhea. Arch Otolaryngol Head Neck Surg. 2000 May;126(5):665-8. [Medline: 10807338] [doi: 10.1001/archotol.126.5.665]

14. Nahlieli O, Lewkowicz A, Hasson O, Vered M. Ganglion cyst of the temporomandibular joint: report of case and review of literature. J Oral Maxillofac Surg. 2000 Feb;58(2):216-9. [Medline: 10670602] [doi: 10.1016/S0278-2391(00)90342-2]

15. Goudot P, Jaquinet AR, Richter M. Cysts of the temporomandibular joint. Report of two cases. Int J Oral Maxillofac Surg. 1999 Oct;28(5):338-40. [Medline: 10535531] [doi: 10.1016/S0901-5027(99)80077-0]

16. Chang YM, Chan CP, Kung Wu SF, Hao SP, Chang LC. Ganglion cyst and synovial cyst of the temporomandibular joint. Two case reports. Int J Oral Maxillofac Surg. 1997 Jun;26(3):179-81. [Medline: 9180226] [doi: 10.1016/S0901-5027(97)80815-6]

17. Bonacci CE, Lambert BJ, Pulse CL, Israel HA. Inflammatory synovial cyst of the temporomandibular joint: a case report and review of the literature. J Oral Maxillofac Surg. 1996 Jun;54(6):769-73. [Medline: 8648485] [doi: 10.1016/S0278-2391(96)90701-6]

18. Lopes V, Jones JA, Sloan P, McWilliam L. Temporomandibular ganglion or synovial cyst? A case report and literature review. Oral Surg Oral Med Oral Pathol. 1994 Jun;77(6):627-30. [Medline: 8065728] [doi: 10.1016/0030-4220(94)90324-7]

19. McGuirt WF Jr, Myers EN. Ganglion of the temporomandibular joint presentation as a parotid mass. Otolaryngol Head Neck Surg. 1993 Nov;109(5):950-3. [Medline: 8247579] [doi: 10.1177/019459989310900528]

20. Hopper C, Banks P. A ganglion of the temporomandibular joint: a case report. J Oral Maxillofac Surg. 1991 Aug;49(8): 878-80. [Medline: 2072202] [doi: 10.1016/0278-2391(91)90021-D]

21. Farole A, Johnson MW. Bilateral synovial cysts of the temporomandibular joint. J Oral Maxillofac Surg. 1991 Mar;49(3):305-7. [Medline: 1995823] [doi: 10.1016/0278-2391(91)90228-E]

22. Tom BM, Rao VM, Farole A. Bilateral temporomandibular joint ganglion cysts: CT and MR characteristics. AJNR Am J Neuroradiol. 1990 Jul-Aug;11(4):746-8. [Medline: 2114762]

23. el-Massry MA, Bailey BM. Ganglion of the temporomandibular joint. Case report and literature survey. Br J Oral Maxillofac Surg. 1989 Feb;27(1):67-70. [Medline: 2645935] [doi: 10.1016/0266-4356(89)90130-7] 
24. Copeland M, Douglas B. Ganglions of the temporomandibular joint: case report and review of literature. Plast Reconstr Surg. 1988 May;81(5):775-6. [Medline: 3283792] [doi: 10.1097/00006534-198805000-00023]

25. Shiba R, Suyama T, Sakoda S. Ganglion of the temporomandibular joint. J Oral Maxillofac Surg. 1987 Jul;45(7):618-21. [Medline: 3474378 ] [doi: 10.1016/0278-2391(87)90274-6]

26. Kenney JG, Smoot EC, Morgan RF, Shapiro D. Recognizing the temporomandibular joint ganglion. Ann Plast Surg. 1987 Apr;18(4):323-6. [Medline: 3579173] [doi: 10.1097/00000637-198704000-00010]

27. Reychler H, Fievez C, Marbaix E. Synovial cyst of the temporomandibular joint. A case report. J Maxillofac Surg. 1983 Dec;11(6):284-6. [Medline: 6581252] [doi: 10.1016/S0301-0503(83)80067-8]

28. Kinkead LR, Bennett JE, Tomich CE. A ganglion of the temporomandibular joint presenting as a parotid tumor. Head Neck Surg. 1981 May-Jun;3(5):443-5. [Medline: 7239941] [doi: 10.1002/hed.2890030514]

29. Ethell AT. A rare 'parotid tumour'. J Laryngol Otol. 1979 Jul;93(7):741-4. [Medline: 469404] [doi: 10.1017/S0022215100087648]

30. Janecka IP, Conley JJ. Synovial cyst of temporo-mandibular joint imitating a parotid tumour. (A case report). J Maxillofac Surg. 1978 May;6(2):154-6. [Medline: 276556] [doi: 10.1016/S0301-0503(78)80083-6]

31. Deng R, Yang X, Tang E. Ganglion cyst of the temporomandibular joint. Br J Oral Maxillofac Surg. 2010 Apr;48(3): 224-5. [Medline: 19748713] [doi: 10.1016/j.bjoms.2009.08.013]

32. Silva EC, Guimarães AL, Gomes CC, Gomez RS. Ganglion cyst of the temporomandibular joint. Br J Oral Maxillofac Surg. 2005 Feb;43(1):77-80. [Medline: 15620782] [doi: 10.1016/j.bjoms.2004.08.016]

33. Neis J, Tehrani M, Dornhoffer JL. Synovial cyst of the temporomandibular joint: An unusual presentation. Int Adv Otol. 2010;6:(1):116-9. [URL: http://advancedotology.org/sayilar/69/buyuk/IAOJanuary2010p116-1191.pdf]

34. Chen Y, Suzuki M, Siraki S, Kayano T, Amagasa T, Takagi M. Synovial cyst of the temporomandibular joint: Report of a case. Oral Med Pathol. 1998;3:97-9. [doi: 10.3353/omp.3.97]

35. Patel NS, Pellettiere EV, Southwick HW. Intraosseous ganglion of the temporomandibular joint. J Oral Surg. 1979 Nov;37(11):829-31. [Medline: 290777]

36. Heydt S. A ganglion associated with the temporomandibular joint. J Oral Surg. 1977 May;35(5):400-1. [Medline: 265378265378]

37. Steen MW, Hofstede DJ. Ganglion and Synovial Cyst of the Temporomandibular Joint: A Case Report and Literature Review. Plast Reconstr Surg Glob Open. 2015 Sep 23;3(9):e524. [Medline: 26495237] [PMC free article: 4596449] [doi: 10.1097/GOX.0000000000000494]

38. Zheng ZW, Shao X, Yang C, Fang YM. Surgical treatment of temporomandibular disorder in a 24-year-old male patient with ganglion cyst. J Craniofac Surg. 2015 Mar;26(2):560-2. [Medline: 25643336] [doi: 10.1097/SCS.0000000000001231]

39. Lee YT, Kwon SB, Cho SH, Eo S, Rhee SC. A ganglion cyst of the temporomandibular joint. Arch Plast Surg. 2014 Nov;41(6):777-80. [Medline: 25396197] [PMC free article: 4228227] [doi: 10.5999/aps.2014.41.6.777]

40. Levarek RE, Nolan PJ. Temporomandibular Joint Ganglion Cyst:AUnique Case of Complete Resolution Following Subtotal Excision. J Oral Maxillofac Surg. 2016 Sep;74(9):1783-91. [Medline: 27019412] [doi: 10.1016/j.joms.2016.02.022]

41. Partridge JC, Cipriani N, Faquin WC, Chuang SK, Keith DA, Lahey ET. Periarticular Cysts of the Temporomandibular Joint Are More Frequently Synovial Than Ganglion. J Oral Maxillofac Surg. 2016 Jul;74(7):1396-402. [Medline: 26902711] [doi: 10.1016/j.joms.2016.01.036]

\section{To cite this article:}

Maribo Y, Stokbro K, Aagaard E, Larsen SR, Thygesen T.

Synovial Cysts in the Temporomandibular Joint: a Case Report and Critical Review of the Literature

J Oral Maxillofac Res 2019;10(1):e4

URL: http://www.ejomr.org/JOMR/archives/2019/1/e4/v10n1e4.pdf

doi: $\underline{10.5037 / j o m r .2019 .10104}$

Copyright (C) Maribo Y, Stokbro K, Aagaard E, Larsen SR, Thygesen T. Published in the JOURNAL OF ORAL \& MAXILLOFACIAL RESEARCH (http://www.ejomr.org), 31 March 2019.

This is an open-access article, first published in the JOURNAL OF ORAL \& MAXILLOFACIAL RESEARCH, distributed under the terms of the Creative Commons Attribution-Noncommercial-No Derivative Works 3.0 Unported License, which permits unrestricted non-commercial use, distribution, and reproduction in any medium, provided the original work and is properly cited. The copyright, license information and link to the original publication on (http://www.ejomr.org) must be included. 